\title{
ANALISIS INDEKS PEMBANGUNAN MANUSIA (IPM) KABUPATEN BOJONEGORO
}

\author{
Endang Siswati dan Diah Tri Hermawati \\ sis_endang@uwks.ac.id \\ Dosen Program Studi Agribisnis \\ Fakultas Pertanian \\ Universitas Wijaya Kusuma Surabaya
}

\begin{abstract}
ABSTRAK
Analisis Indeks Pembangunan Manusia di Kabupaten Bojonegoro 2018 dengan tujuan (1) mengetahui capaian komponen IPM Kabupaten Bojonegoro, (2) mengetahui keterbandingan angka Indeks Pembangunan Manusia Kabupaten Bojonegoro dengan Kabupaten/Kota di Provinsi Jawa Timur. Metode yang digunakan dalam analisis IPM tersebut adalah IPM dihitung sebagai rata-rata geometrik dari indeks kesehatan, pendidikan, dan pengeluaran. Dalam menghitung IPM, diperlukan nilai minimum dan maksimum untuk masing-masing indikator. Hasil penelitian menunjukkan bahwa Capaian IPM Kabupaten Bojonegoro pada tahun 2016 adalah 66,73 dan pada tahun 2017 sebesar 67,28 naik sebesar 0,23 point. Nilai IPM Kabupaten Bojonegoro bila menurut UNDP termasuk kedalam tingkat pembangunan "sedang". Dengan nilai tersebut IPM Kabupaten Bojonegoro berada pada peringkat ke-26 dari 38 kabupaten/kota se Jawa Timur, dan posisi ini tidak berubah dari tahun sebelumnya. Pada tahun 2017 terjadi peningkatan pada seluruh indikator penyusun IPM. Indeks kesehatan yang diwakili dimensi Umur Panjang dan Hidup Sehat naik yang ditunjukkan dengan meningkatnya angka harapan hidup (AHH) menjadi 70,83 tahun dibandingkan tahun sebelumnya masih sebesar 70,67 tahun. Selanjutnya Indeks pendidikan yang diwakli oleh dimensi naik dengan meningkatnya angka harapan lama sekolah (HLS) menjadi 12,34 tahun, dan rata-rata lama sekolah (RLS) menjadi 6,71 tahun dibandingkan tahun 2016. Indeks daya beli yang diwakili oleh dimensi pengeluaran juga naik yang ditunjukkan dengan meningkatnya pengeluaran per kapita per tahun menjadi 9,420 juta rupiah pada tahun 2016 dibandingkan tahun 2015 yang sebesar 9,553 juta rupiah per kapita penduduk per tahun.
\end{abstract}

Kata Kunci: Analisis, Indeks, Manusia.

\section{PENDAHULUAN}

\section{Latar Belakang}

Pembangunan manusia adalah sebuah proses dan hasil yaitu proses memperbesar pilihan orang tetapi juga menjadi tujuan. Pembangunan manusia mengimplikasikan bahwa orang harus mempengaruhi proses yang membentuk kehidupan mereka. Pertumbuhan ekonomi merupakan sarana penting bagi pembangunan manusia, namun tidak pada akhirnya. Pembangunan manusia adalah pengembangan masyarakat melalui pembangunan kemampuan manusia, oleh masyarakat melalui partisipasi aktif dalam proses yang membentuk kehidupan dan masyarakat dengan memperbaiki kehidupan mereka. Ini lebih luas daripada pendekatan lain, seperti pendekatan sumber daya manusia, pendekatan kebutuhan dasar dan pendekatan kesejahteraan manusia. Indeks Pembangunan Manusia gabungan (IPM) mengintegrasikan tiga dimensi dasar pembangunan manusia. Harapan hidup saat lahir mencerminkan kemampuan untuk 
menjalani hidup yang panjang dan sehat. Tahun bersekolah dan tahun-tahun sekolah yang diharapkan mencerminkan kemampuan untuk memperoleh pengetahuan. Dan pendapatan nasional bruto per kapita mencerminkan kemampuan untuk mencapai standar kehidupan yang layak. (Human Development Report Office).

Dewasa ini di kalangan pengambil kebijakan telah sadar akan pentingnya pembangunan di bidang sumber daya manusia. Kesadaran ini tumbuh setelah dirasakan bahwa pembangunan yang cenderung berorientasi pada pertumbuhan ternyata menghasilkan kesenjangan yang sangat besar baik antara pertumbuhan ekonomi dengan pemerataan, pertumbuhan ekonomi yang tidak diikuti oleh penyerapan tenaga kerja, adanya kualitas hidup yang rendah, tingkat pendidikan yang tidak merata, daya beli masyarakat yang menurun drastis dan lain sebagainya. Padahal rendahnya pembangunan di bidang manusia juga akan melemahkan sendi-sendi perekonomian secara menyeluruh, karena pembangunan manusia yang baik mempunyai multiplier effects ke berbagai bidang. Multiplier effects yang dimaksud adalah efek penyebaran yang ditimbulkan dari suatu Penelitian yang berdampak pada Penelitian lain karena Penelitian tersebut mempunyai keterkaitan atau saling tergantung satu sama lain, misalnya dengan semakin membaiknya pendidikan dan kesehatan manusia maka dengan sendirinya memperbaiki tingkat pendapatannya, dan seterusnya akan menciptakan pula Penelitian lain yang sifatnya forward linkage seperti peningkatan pelayanan. Dalam rangka melengkapi indikator pengukuran keberhasilan pembangunan, maka perlu diukur dari aspek yang langsung berkaitan dengan kesejahteraan dan kualitas hidup setiap penduduk Indonesia. Ukuran yang dapat menunjukkan hal tersebut yaitu Indeks Pembangunan Manusia (IPM) atau biasa disebut Human Development Index (HDI). Indeks ini dapat menggambarkan kondisi kualitas hidup penduduk dari sisi kualitatif (non ekonomi) maupun kuantitatif (ekonomi). Cara pengukurannya pun berdasarkan penghitungan variabel individu penduduk, bukan variabel akumulatif atau kolektif, misal pertumbuhan ekonomi diukur dari perubahan output total penduduk tanpa melihat siapa penghasilnya.

UNDP (United Nation Development Programme) memberikan ukuran terhadap keberhasilan pembangunan manusia yakni dengan Indeks Pembangunan Manusia (Human Development Index). Indeks Pembangunan Manusia atau disingkat IPM merupakan indeks komposit yang dihitung sebagai rata-rata dari Indeks Harapan Hidup, Indeks Pendidikan dan Indeks Standar Hidup Layak yang tertuang dalam Paritas Daya Beli (purchasing power parity). Sejak otonomi daerah, maka setiap daerah diharapkan untuk mengetahui ukuran IPM daerahnya sendiri baik untuk keperluan perencanaan maupun untuk evaluasi khususnya dalam mengetahui perkembangan dan sebaran hasilhasil pembangunan bidang manusia.

Secara umum IPM Kabupaten Bojonegoro dari tahun ke tahun mengalami peningkatan akan tetapi peningkatannya lamban. Peningkatan IPM di Kabupaten Bojonegoro sangat mungkin sepanjang semua elemen bergerak bersama, karena banyak hal hambatan terutama dari sisi budaya (nilai-nilai lokal dan modal sosial). Disepanjang hal tersebut harus diketahui nilai masing-masing komponen yang mendukung IPM tersebut pada tiap-tiap kecamatan di Kabupaten Bojonegoro, karena dengan mengetahui nilai di masing-masing kecamatan akan diketahui kecamatan mana yang nilainya rendah dan perlu intervensi penanganannya. Maka rencana di tahun 2018 adalah perhitungan dan analisa IPM Kabupaten Bojonegoro yang akan ditampilkan angka-angka capaian per kecamatan. 


\section{Rumusan Masalah}

Pengukuran keberhasilan pembangunan di seluruh wilayah Kabupaten Bojonegoro perlu diukur dengan angka IPM. Angka ini dapat menunjukkan sejauh mana tingkat pencapaian pembangunan daerah dalam meningkatkan kesejahteraan penduduknya. Untuk mengukur hal tersebut maka penelitian ini akan membahas permasalahan berikut:

1. Seberapa besar pencapaian komponen IPM Kabupaten Bojonegoro dilihat dari aspek: tingkat kesehatan penduduk, tingkat pendidikan dan pengetahuan penduduk serta kemampuan daya beli (standar kelayakan hidup) penduduk?

2. Bagaimana perbandingan pencapaian Indeks Pembangunan Manusia (IPM) di Kabupaten Bojonegoro dengan kabupaten/Kota di Jawa Timur?

\section{Tujuan Penelitian}

Berdasarkan rumusan masalah, maka tujuan yang ingin dicapai dalam penelitian ini adalah:

1. Mengetahui capaian komponen IPM Kabupaten Bojonegoro dilihat dari aspek: tingkat kesehatan penduduk, tingkat pendidikan dan pengetahuan penduduk serta kemampuan daya beli (standar kelayakan hidup) penduduk.

2. Mengetahui keterbandingan angka Indeks Pembangunan Manusia Kabupaten Bojonegoro dengan Kabupaten/Kota di Provinsi Jawa Timur

\section{Sasaran Penelitian}

Sasaran penelitian Indeks Pembangunan Manusia Kabupaten Bojonegoro Tahun Anggaran 2018 ini adalah:

1. Diketahuinya tingkat kesejahteraan masyarakat berdasarkan besaran komponen unsur pembentuk Indeks Pembangunan Manusia;

2. Tersedianya rekomendasi kebijakan intervensi perbaikan sektoral berdasarkan kewilayahan dan disparitas kesejahteraan penduduk;

3. Terumuskannya kebijakan pembangunan yang berbasis pada data dan informasi

4. Terukurnya tingkat kualitas hidup penduduk Kabupaten Bojonegoro secara kualitatif dilihat dari tingkat kesehatan, pendidikan dan pengetahuan penduduk; perkecamatan seingga bisa di ketahui disparitas pencapaian nya.

\section{Lingkup Pelaksanaan Pekerjaan}

Lingkup Penelitian Indeks Pembangunan Manusia (IPM) meliputi 3 (tiga) komponen antara lain:

1. Angka Harapan Hidup (Life Expectation of Age), jumlah rata-rata tahun (umur) yang diharapkan oleh seseorang yang baru lahir untuk dijalani sampai meninggal kelak.

2. Angka Melek Huruf penduduk dewasa (Adult Literacy Rate /LIT) dan rata-rata lama sekolah (Mean Years of Schooling/MYS) yakni mengukur pengetahuan (knowledge) dan ketrampilan (skill).

3. Paritas daya beli (Purchasing Power Parity) merupakan ukuran pendapatan yang sudah disesuaikan dengan paritas daya beli.

\section{Keluaran (Output)}

Penelitian Indeks Pembangunan Manusia (IPM) Kabupaten Bojonegoro Tahun 2018 diharapkan akan menghasilkan "Dokumen Indeks Pembangunan Manusia (IPM) 
Kabupaten Bojonegoro Tahun 2018" yang memuat substansi materi sebagai berikut:

1. Indeks Pembangunan Manusia Kabupaten Bojonegoro beserta tiga komponen pembentuknya.

2. Upaya-upaya peningkatan dan faktor-faktor pencapaian IPM

3. Posisi capaian IPM Kabupaten Bojonegoro di antara IPM kabupaten lainnya di Jawa Timur selama lima tahun terakhir

4. Disparitas level kecamatan serta keterkaitan antara input, proses, dan output pembangunan manusia di wilayah Kabupaten Bojonegoro.

5. Kontribusi dan peran pembangunan manusia (dilihat dari IPM) terhadap pertumbuhan ekonomi Kabupaten Bojonegoro

6. Mengetahui arahan pengambilan kebijakan terkait pemberdayaan sumber daya manusia di kabupaten Bojonegoro.

\section{TINJAUAN PUSTAKA}

\section{Pengertian Indeks Pembangunan manusia}

Menurut UNDP (United Nations Development Programme), pembangunan manusia adalah suatu proses untuk memperbesar pilihan-pilihan bagi manusia. Konsep atau definisi pembangunan manusia tersebut pada dasarnya mencakup dimensi pembangunan yang sangat luas. Dalam konsep pembangunan manusia, pembangunan seharusnya dianalisis serta dipahami dari sudut manusianya, bukan hanya dari pertumbuhan ekonominya. Sebagaimana dikutip dari UNDP (Human Development Report, 1995:103), sejumlah premis penting dalam pembangunan manusia adalah:

- Pembangunan harus mengutamakan penduduk sebagai pusat perhatian.

- Pembangunan dimaksudkan untuk memperbesar pilihan-pilihan bagi penduduk, tidak hanya untuk meningkatkan pendapatan mereka. Oleh karena itu konsep pembangunan manusia harus terpusat pada penduduk secara keseluruhan, dan bukan hanya pada aspek ekonomi saja.

- Pembangunan manusia memperhatikan bukan hanya pada upaya meningkatkan kemampuan (kapabilitas) manusia tetapi juga dalam upaya-upaya memanfaatkan kemampuan manusia tersebut secara optimal.

- Pembangunan manusia didukung oleh empat pilar pokok, yaitu: produktifitas, pemerataan, kesinambungan, dan pemberdayaan.

- Pembangunan manusia menjadi dasar dalam penentuan tujuan pembangunan dan dalam menganalisis pilihan-pilihan untuk mencapainya.

Berdasarkan konsep tersebut, penduduk di tempatkan sebagai tujuan akhir sedangkan upaya pembangunan dipandang sebagai sarana untuk mencapai tujuan itu. Untuk menjamin tercapainya tujuan pembangunan manusia, ada empat hal pokok yang perlu diperhatikan yaitu:

\section{Produktivitas}

Penduduk harus meningkatkan produktifitas dan partisipasi penuh dalam proses penciptaan pendapatan dan nafkah. Sehingga pembangunan ekonomi merupakan bagian dari model pembangunan manusia.

2. Pemerataan

Penduduk memiliki kesempatan yang sama untuk mendapatkan akses terhadap sumber daya ekonomi dan sosial. Semua hambatan yang memperkecil kesempatan untuk memperoleh akses tersebut harus dihapus, sehingga mereka dapat mengambil manfaat dari kesempatan yang ada dan berpartisipasi dalam Penelitian produktif yang 
dapat meningkatkan kualitas hidup

3. Kesinambungan

Akses terhadap sumber daya ekonomi dan sosial harus dipastikan tidak hanya untuk generasi-generasi yang akan datang. Semua sumber daya fisik, manusia, dan lingkungan selalu diperbaharui.

4. Pemberdayaan

Penduduk harus berpartisipasi penuh dalam keputusan dan proses yang akan menentukan (bentuk/arah) kehidupan mereka serta untuk berpartisipasi dan mengambil keputusan dalam proses pembangunan.

Sebenarnya paradigma pembangunan manusia tidak hanya berhenti sampai di sana. Pilihan-pilihan tambahan yang dibutuhkan dalam masyarakat luas seperti kebebasan politik,ekonomi dan sosial, sampai kesempatan untuk menjadi kreatif dan produktif, dan menikmati kehidupan yang sesuai dengan harkat pribadi dan jasmani.

\section{Komponen Pembangunan Manusia}

Lembaga United Nations Development Programme (UNDP) telah mempublikasikan laporan pembangunan sumber daya manusia dalam ukuran kuantitatif yang disebut Human Development Indeks (HDI). Meskipun HDI merupakan alat ukur pembangunan sumber daya manusia yang dirumuskan secara konstan, diakui tidak akan pernah menangkap gambaran pembangunan sumber daya manusia secara sempurna.

Adapun indikator yang dipilih untuk mengukur dimensi HDI adalah sebagai berikut: (UNDP, Human Development Report 1993: 105-106)

- Longevity, diukur dengan variabel harapan hidup saat lahir atau life expectancy of birth dan angka kematian bayi per seribu penduduk atau infant mortality rate.

- Educational Achievement, diukur dengan dua indikator, yakni melek huruf penduduk usia 15 tahun ke atas (adult literacy rate) dan tahun rata-rata bersekolah bagi penduduk 25 tahun ke atas (the mean years of schooling).

- Access to resource, dapat diukur secara makro melalui PDB rill perkapita dengan terminologi purchasing power parity dalam dolar AS dan dapat dilengkapi dengan tingkatan angkatan kerja.

Dari penjelasan tersebut dapat disimpulkan bahwa komponen-komponen yang mempengaruhi IPM antara lain

1. Derajat kesehatan dan panjangnya umur yang terbaca dari angka harapan hidup (life expecntacy rate), parameter kesehatan dengan indikator angka harapan hidup, mengukur keadaan sehat dan berumur panjang.

2. Pendidikan yang diukur dengan angka melek huruf rata-rata lamanya sekolah, parameter pendidikan dengan angka melek huruf dan lamanya sekolah, mengukur manusia yang cerdas, kreatif, terampil, dan bertaqwa.

3. Pendapatan yang diukur dengan daya beli masyarakat (purchasing power parity), parameter pendapatan dengan indikator daya beli masyarakat, mengukur manusia yang mandiri dan memiliki akses untuk layak.

\section{Pengukuran Pembangunan Manusia}

Indikator komposit pembangunan manusia adalah alat ukur yang dapat digunakan untuk melihat pencapaian pembangunan manusia antar wilayah dan antar waktu. Indeks Pembangunan Manusia (IPM) merupakan alat ukur yang dapat menunjukkan presentase pencapaian dalam pembangunan manusia dengan memperhatikan tiga faktor yaitu: kelangsungan hidup, pengetahuan, dan daya beli. 
Analisis Indeks Pembangunan Manusia (IPM) Kabupaten Bojonegoro (Endang Siswati dan Diah Tri Hermawati)

Tabel 1

Kriteria Komponen Pembangunan Manusia

\begin{tabular}{|l|l|c|c|}
\hline \multicolumn{1}{|c|}{ Faktor } & \multicolumn{2}{|c|}{ Komponen } & \multicolumn{2}{c|}{} \\
\cline { 3 - 4 } & & Maksimum & Minimum \\
\hline Kelangsungan hidup & Angka Harapan Hidup (AHHo) tahun & 85 & 20 \\
\hline \multirow{2}{*}{ Pengetahuan } & Harapan Lama Sekolah (HLS) tahun & 18 & 0 \\
\cline { 2 - 4 } & Rata-rata lama sekolah (thn) & 15 & 0 \\
\hline Daya Beli & Pengeluaran per perkapita (Rp) & 26.572 .352 & 1.007 .436 \\
\hline
\end{tabular}

Sumber: UNDP, Human Development Report

Dengan tiga ukuran pembangunan tersebut dan menerapkan suatu formula yang kompleks terhadap data 160 negara pada tahun 1990, rangking HDI (Human Development Index) semua negara dibagi menjadi 3 (tiga) kelompok, yaitu

1. Negara dengan pembangunan manusia yang rendah (low human development) bila nilai HDI berkisar 0,0 hingga 0,50 .

2. Negara dengan pembangunan manusia yang menengah (medium human development) bila nilai HDI berkisar antara 0,51 hingga 0,79 .

3. Negara dengan pembangunan manusia yang tinggi (high human development) bila nilai HDI berkisar antara 0,80 hingga 1,0 .

Dapat disimpulkan bahwa negara dengan nilai HDI dibawah 0,51 hingga 0,79 dapat dikatakan bahwa negara tersebut mulai memperhatikan pembangunan manusianya, sedangkan negara dengan nilai HDI 0,8 berarti negara tersebut sangat memperhatikan pembangunan manusianya.

Penghitungan IPM sebagai indikator pembangunan manusia memiliki tujuan penting, diantaranya:

- Membangun indikator yang mengukur dimensi dasar pembangunan manusia dan perluasan kebebasan memilih.

- Memanfaatkan sejumlah indikator untuk menjaga ukuran tersebut sederhana.

- Membentuk satu indeks komposit dari pada menggunakan sejumlah indeks dasar.

- Menciptakan suatu ukuran yang mencakup aspek sosial dan ekonomi.

Indeks pembangunan manusia merupakan indeks dasar yang tersusun dari dimensi-dimensi: (1) Umur panjang dan kehidupan yang sehat, dengan indikator angka harapan hidup, (2) Pengetahuan, yang diukur dengan Harapan Lama Sekolah (HLS) dan Rata-rata Lama Sekolah (RLS), dan (3) Standar hidup yang layak, dengan indicator pengeluaran per kapita disesuaikan.

Konsep Pembangunan Manusia yang dikembangkan oleh Perserikatan BangsaBangsa (PBB), menetapkan peringkat kinerja pembangunan manusia pada skala 0,0 100,0 dengan kategori sebagai berikut :

- Sangat Tinggi : IPM $\geq 80$

- Tinggi : IPM antara $70 \leq \mathrm{IPM}<80$

- Sedang : IPM antara $60 \leq \mathrm{IPM}<70$

- Rendah : IPM $<60$

\section{Angka Harapan Hidup}

Angka Harapan Hidup (AHH), dijadikan indikator dalam mengukur kesehatan suatu individu di suatu daerah. Angka Harapan Hidup (AHH) adalah rata-rata perkiraan banyak tahun yang dapat ditempuh seseorang selama hidup. Angka Harapan Hidup $(\mathrm{AHH})$ diartikan sebagai umur yang mungkin dicapai seseorang yang lahir pada tahun 
tertentu. Angka harapan hidup dihitung menggunakan pendekatan tak langsung (indirect estimation). Ada dua jenis data yang digunakan dalam penghitungan Angka Harapan Hidup (AHH) yaitu Anak Lahir Hidup (ALH) dan Anak Masih Hidup (AMH). Sementara itu untuk menghitung indeks harapan hidup digunakan nilai maksimum harapan hidup sesuai standar UNDP, dimana angka tertinggi sebagai batas atas untuk penghitungan indeks dipakai 85 tahun dan terendah 25 tahun (standar UNDP). Usia harapan hidup dapat panjang jika status kesehatan, gizi, dan lingkungan yang baik.

\section{Pengeluaran Per Kapita Disesuaikan}

Indikator pengeluaran perkapita digunakan untuk mengukur standar hidup manusia. Indikator ini juga dipengaruhi oleh pengetahuan serta peluang yang ada untuk merealisasikan pengetahuan dalam berbagai Penelitian produktif sehingga menghasilkan output baik berupa barang maupun jasa sebagai pendapatan. Kemudian pendapatan yang ada menciptakan pengeluaran atau konsumsi. Pengeluaran perkapita memberikan gambaran tingkat daya beli PPP (Purchasing Power Parity) masyarakat, dan sebagai salah satu komponen yang digunakan dalam melihat status pembangunan manusia di suatu wilayah. Rata-rata pengeluaran per kapita setahun diperoleh dari SUSENAS, dihitung dari level provinsi hingga level kab/kota. Rata-rata pengeluaran per kapita dibuat konstan/riil dengan tahun dasar 2012=100. Perhitungan paritas daya beli pada metode baru menggunakan 96 komoditas dimana 66 komoditas merupakan makanan dan sisanya merupakan komoditas nonmakanan. Metode penghitungan paritas daya beli menggunakan Metode Rao.

\section{Rata-rata Lama Sekolah}

Rata-rata lama sekolah mengindikasikan makin tingginya pendidikan yang dicapai oleh masyarakat di suatu daerah. Semakin tinggi rata-rata lama sekolah berarti semakin tinggi jenjang pendidikan yang dijalani. Asumsi yang berlaku secara umum bahwa semakin tinggi tingkat pendidikan seseorang maka semakin tinggi pula kualitas seseorang, baik pola pikir maupun pola tindakannya. Rata-rata Lama Sekolah didefinisikan sebagai jumlah tahun yang digunakan oleh penduduk dalam menjalani pendidikan formal. Diasumsikan bahwa dalam kondisi normal rata-rata lama sekolah suatu wilayah tidak akan turun. Cakupan penduduk yang dihitung dalam penghitungan rata-rata lama sekolah adalah penduduk berusia 25 tahun ke atas.

1. Rata-rata Lama Sekolah - RLS (Mean Years of Schooling - MYS)

Rata-rata Lama Sekolah didefinisikan sebagai jumlah tahun yang digunakan oleh penduduk dalam menjalani pendidikan formal. Diasumsikan bahwa dalam kondisi normal rata-rata lama sekolah suatu wilayah tidak akan turun. Cakupan penduduk yang dihitung dalam penghitungan rata-rata lama sekolah adalah penduduk berusia 25 tahun ke atas.

2. Angka Harapan Lama Sekolah - HLS (Expected Years of Schooling EYS)

Angka Harapan Lama Sekolah didefinisikan lamanya sekolah (dalam tahun) yang diharapkan akan dirasakan oleh anak pada umur tertentu di masa mendatang. Diasumsikan bahwa peluang anak tersebut akan tetap bersekolah pada umur- umur berikutnya sama dengan peluang penduduk yang bersekolah per jumlah penduduk untuk umur yang sama saat ini. Angka Harapan Lama Sekolah dihitung untuk penduduk berusia 7 tahun ke atas. HLS dapat digunakan untuk mengetahui kondisi pembangunan sistem pendidikan di berbagai jenjang yang ditunjukkan dalam bentuk 
lamanya pendidikan (dalam tahun) yang diharapkan dapat dicapai oleh setiap anak.

\section{Angka Harapan Lama Sekolah - HLS (Expected Years of Schooling EYS)}

Salah satu indikator yang dapat dijadikan ukuran kesejahteraan sosial yang merata adalah Angka Harapan Lama Sekolah. HLS mendefinisikan lamanya sekolah (dalam tahun) yang diharapkan akan dirasakan oleh anak pada umur tertentu di masa mendatang. Diasumsikan bahwa peluang anak tersebut akan tetap bersekolah pada umur-umur berikutnya sama dengan peluang penduduk yang bersekolah per jumlah penduduk untuk umur yang sama saat ini. Angka Harapan Lama Sekolah dihitung untuk penduduk berusia 7 tahun ke atas. HLS dapat digunakan untuk mengetahui kondisi pembangunan sistem pendidikan di berbagai jenjang yang ditunjukkan dalam bentuk lamanya pendidikan (dalam tahun) yang diharapkan dapat dicapai oleh anak.

\section{METODE PENELITIAN \\ Ruang Lingkup Penelitian}

Penelitian Penyusunan Penyusunan Indeks Pembangunan Manusia (IPM) Kabupaten Bojonegoro Tahun 2018 ini meliputi lokasi seluruh wilayah Kabupaten Bojonegoro.

\section{Jenis Dan Sumber Data}

Dilihat dari sumbernya, data yang digunakan dalam Penelitian ini adalah data sekunder. Data ini merupakan data yang telah dikumpulkan oleh pihak lain. Adapun data sekunder yang akan digunakan dalam penelitian ini diantaranya data kependudukan, pendidikan dan ekonomi.

Data-data yang sudah diuraikan dimuka akan dikumpulkan dari berbagai sumber yang dapat dipertanggungjawabkan, yaitu:

1. Badan Pusat Statistik (BPS) Kabupaten Bojonegoro.

2. Dinas Pendidikan Kabupaten Bojonegoro.

3. Dinas Kesehatan Kabupaten Bojonegoro.

4. Dinas Tenaga Kerja Kabupaten Bojonegoro.

\section{Metode Pengumpulan Data}

Dalam pengumpulan data, metode yang digunakan dalam penelitian ini adalah dokumentasi, dengan cara mengutip atau menyalin dokumen-dokumen yang relevan untuk digunakan sebagai data dalam penelitian ini.

\section{Metode Perhitungan IPM}

Pada tahun 2014, Indonesia secara resmi melakukan penghitungan IPM dengan metode baru. Untuk mengaplikasikan metode baru, sumber data yang tersedia di Indonesia antara lain:

1. Angka harapan hidup saat lahir (Sensus Penduduk 2010/SP2010, Proyeksi Penduduk)

2. Angka harapan lama sekolah dan rata-rata lama sekolah (Survei Sosial Ekonomi Nasional/SUSENAS 2015)

3. PNB per kapita tidak tersedia pada tingkat provinsi dan kabupaten/ kota, sehingga diproksi dengan pengeluaran per kapita disesuaikan menggunakan data SUSENAS 2015. 
Beberapa penyesuaian yang dilakukan terhadap metode baru dilakukan pada indikator PNB per kapita karena masalah ketersediaan data. Dari empat indikator yang digunakan dalam penghitungan IPM metode baru, tiga diantaranya sama persis dengan UNDP. Khusus untuk PNB per kapita, indikator ini diproksi dengan pengeluaran per kapita. Perbedaan indikator antara metode lama dan metode baru perhitungan IPM adalah sebagai berikut:

Tabel 2

Perbedaan Indikator Metode Lama dan Metode Baru UNDP

\begin{tabular}{|c|c|c|}
\hline Dimensi & Metode Lama & Metode Baru \\
\hline $\begin{array}{l}\text { Kesehatan } \\
\text { Umur Panjang } \\
\text { dan Hidup } \\
\text { Sehat }\end{array}$ & $\begin{array}{l}\text { Angka Harapan Hidup saat Lahir } \\
(\mathrm{AHH})\end{array}$ & $\begin{array}{l}\text { Angka Harapan Hidup saat Lahir } \\
(\mathrm{AHH})\end{array}$ \\
\hline Pengetahuan & 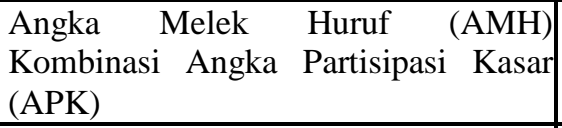 & $\begin{array}{l}\text { Harapan Lama Sekolah (HLS) } \\
\text { Rata-Rata Lama Sekolah (RLS) }\end{array}$ \\
\hline $\begin{array}{l}\text { Standar } \\
\text { Hidup Layak }\end{array}$ & PDB per Kapita & $\begin{array}{l}\text { Pengeluaran per Kapita } \\
\text { Disesuaikan }\end{array}$ \\
\hline Agregasi & 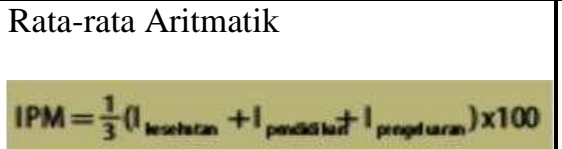 & 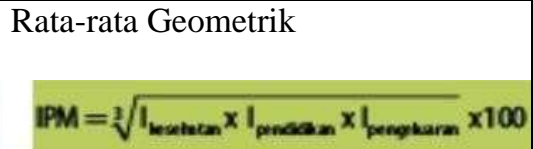 \\
\hline
\end{tabular}

Sumber: Indeks Pembangunan Manusia 2015, BPS 2016

Dengan menggunakan rata-rata geometrik dalam menyusun IPM dapat diartikan bahwa capaian satu dimensi tidak dapat ditutupi oleh capaian pada dimensi lain. Artinya, untuk mewujudkan pembangunan manusia yang baik, ketiga dimensi harus memperoleh perhatian yang sama besar karena sama pentingnya.

\section{Perhitungan Indeks Komponen IPM}

Setiap komponen IPM distandardisasi dengan nilai minimum dan maksimum sebelum digunakan untuk menghitung IPM. Rumus yang digunakan sebagai berikut. (BPS, 2016)

Dimensi Kesehatan :

$$
I_{\text {inestite }}=\frac{A H H-A H H_{m i n}}{A H H_{\max }-A H H_{\min }}
$$

Dimensi Pendidikan :

$$
\begin{aligned}
& I_{\text {ML }}=\frac{H L S-H L S_{m}}{H L S_{m e s}-H L S_{m e}} \\
& I_{\text {es }}=\frac{\text { RLS }- \text { RLS }}{\text { RLS }_{m=0}-\text { RLS }_{m t}} \\
& I_{\text {masum }}=\frac{I_{n e s}+I_{n s}}{2}
\end{aligned}
$$

Dimensi Pengeluaran :

$$
I_{m x_{a m}}=\frac{\ln (\text { pengeluaran })-\operatorname{In}\left(\text { pengeluara }_{m e}\right)}{\ln \left(\text { pengeluaran }_{\max }\right)-\operatorname{In}\left(\text { pengeluaran }_{m=1}\right)}
$$

\section{Menghitung IPM} pengeluaran.

IPM dihitung sebagai rata-rata geometrik dari indeks kesehatan, pendidikan, dan

$$
I P M=\sqrt[3]{I_{\text {inetuten }} x I_{\text {penddian }} x I_{\text {pengduase }}} \times 100
$$


Penentuan Nilai Minimum dan Maksimum

Dalam menghitung IPM, diperlukan nilai minimum dan maksimum untuk masing-masing indikator. Pada tabel 4 berikut disajikan nilai-nilai tersebut.

Tabel 3

Penentuan Nilai Minimum dan Maksimum

\begin{tabular}{|c|c|c|c|c|c|}
\hline \multirow[b]{2}{*}{ Indikator } & \multirow[b]{2}{*}{ Satuan } & \multicolumn{2}{|c|}{ Minimum } & \multicolumn{2}{|c|}{ Maksimum } \\
\hline & & UNDP & BPS & UNDP & BPS \\
\hline $\begin{array}{l}\text { Angka Harapan Hidup Saat } \\
\text { Lahir }\end{array}$ & Tahun & 20 & 20 & 85 & 85 \\
\hline Angka Harapan Lama Sekolah & Tahun & 0 & 0 & 18 & 18 \\
\hline Rata-rata Lama Sekolah & Tahun & 0 & 0 & 15 & 15 \\
\hline $\begin{array}{l}\begin{array}{l}\text { Pengeluaran per } \\
\text { Disesuaikan }\end{array} \\
\text { Kapita }\end{array}$ & & $\begin{array}{c}100 \\
\text { (PPPUS) }\end{array}$ & $\begin{array}{l}1.007 .436^{*} \\
(\mathrm{Rp})\end{array}$ & $\begin{array}{l}107.721 \\
\text { (PPPUS) }\end{array}$ & $\begin{array}{l}26.572 .352^{* *} \\
\quad(\mathrm{Rp})\end{array}$ \\
\hline
\end{tabular}

Keterangan:

Daya beli minimum merupakan garis kemiskinan terendah kabupaten tahun 2010 (data empiris) yaitu di Tolikara-Papua

** Daya beli maksimum merupakan nilai tertinggi kabupaten yang diproyeksikan hingga 2025 (akhir RPJPN) yaitu perkiraan pengeluaran per kapita Jakarta Selatan tahun 2025

\section{Variabel dalam IPM Metode Baru}

Variabel dalam perhitungan IPM metode baru sebagaimana dikutip dari Indeks Pembangunan Manusia 2015, BPS 2016 antara lain meliputi:

1) Angka Harapan Hidup Saat Lahir - AHH (Life Expectancy - $e_{0}$ ) Angka Harapan Hidup saat Lahir didefinisikan sebagai rata-rata perkiraan banyak tahun yang dapat ditempuh oleh seseorang sejak lahir. AHH mencerminkan derajat kesehatan suatu masyarakat. AHH dihitung dari hasil sensus dan survei kependudukan.

2) Rata-rata Lama Sekolah - RLS (Mean Years of Schooling - MYS), Rata-rata Lama Sekolah didefinisikan sebagai jumlah tahun yang digunakan oleh penduduk dalam menjalani pendidikan formal. Diasumsikan bahwa dalam kondisi normal rata-rata lama sekolah suatu wilayah tidak akan turun. Cakupan penduduk yang dihitung dalam penghitungan rata-rata lama sekolah adalah penduduk berusia 25 tahun ke atas.

3) Angka Harapan Lama Sekolah-HLS (Expected Years of Schooling EYS),Angka Harapan Lama Sekolah didefinisikan lamanya sekolah (dalam tahun) yang diharapkan akan dirasakan oleh anak pada umur tertentu di masa mendatang. Diasumsikan bahwa peluang anak tersebut akan tetap bersekolah pada umur- umur berikutnya sama dengan peluang penduduk yang bersekolah per jumlah penduduk untuk umur yang sama saat ini. Angka Harapan Lama Sekolah dihitung untuk penduduk berusia 7 tahun ke atas. HLS dapat digunakan untuk mengetahui kondisi pembangunan sistem pendidikan di berbagai jenjang yang ditunjukkan dalam bentuk lamanya pendidikan (dalam tahun) yang diharapkan dapat dicapai.

4) Pengeluaran per Kapita Disesuaikan,Pengeluaran per kapita yang disesuaikan ditentukan dari nilai pengeluaran per kapita dan paritas daya beli (Purcashing Power Parity-PPP). Rata-rata pengeluaran per kapita setahun diperoleh dari SUSENAS, dihitung dari level provinsi hingga level kab/kota. Rata-rata pengeluaran per kapita 
dibuat konstan/riil dengan tahun dasar 2012=100. Perhitungan paritas daya beli pada metode baru menggunakan 96 komoditas dimana 66 komoditas merupakan makanan dan sisanya merupakan komoditas nonmakanan. Metode penghitungan paritas daya beli menggunakan Metode Rao.

\section{Pengelompokan IPM}

Untuk melihat capaian IPM antar wilayah dapat dilihat melalui pengelompokkan IPM ke dalam beberapa kategori, yaitu: (BPS 2015)

- IPM $<60 \quad$ : IPM rendah

- $60 \leq \mathrm{IPM}<70 \quad$ : IPM sedang

- $70 \leq$ IPM $<80$ : IPM tinggi

- IPM $\geq 80 \quad$ : IPM sangat tinggi

\section{HASIL DAN PEMBAHASAN IPM}

Konsep pembangunan manusia memenuhi dimensi yang sangat luas dengan banyak pilihan, hanya mungkin tercapai jika penduduk tersebut memiliki peluang angka harapan hidup yang tinggi atau umur panjang dan sehat, memiliki pengetahuan dan ketrampilan atau keahlian serta mempunyai peluang atau kesempatan merealisasikan pengetahuan tersebut dalam Penelitian produktif, sehingga masyarakat atau penduduk memiliki daya beli yang tinggi.

Indeks Pembangunan Manusia (IPM) adalah indikator yang digunakan untuk mengukur salah satu aspek penting yang berkaitan dengan kualitas dari hasil-hasil pembangunan ekonomi, yakni derajat perkembangan manusia. IPM merupakan suatu indeks komposisi yang didasarkan pada 3 (tiga) indikator yakni, kesehatan, pendidikan yang dicapai dan standar kehidupan.

Indeks Pembangunan Manusia (IPM) Kabupaten Bojonegoro dari tahun ketahun selalu meningkat, pada tahun 2013 pencapaian IPM Kabupaten Bojonegoro sebesar 64.85 meningkat sebesar 1.58 point pada tahun 2014 yang sebesar 65.27. dan pada tahun 2015 angka IPM Kabupaten Bojonegoro sebesar 66.17 meningkat 1.07 point dibandingkan angka IPM tahun 2014. Pada tahun 2016 angka IPM Kabupaten Bojonegoro menjadi 65.73 meningkat 0.56 dari angka IPM tahun 2015.

Untuk mengetahui kemajuan tersebut dan sejauh mana keadaan sumber daya manusia di Kabupaten Bojonegoro, akan dibahas indikator-indikator tunggal seperti keadaan pendidikan, kesehatan, dan ketenagakerjaan yang selanjutnya akan dikaitkan dengan hasil perhitungan angka IPM.

\section{Perkembangan Indeks Pembangunan Manusia Kabupaten Bojonegoro 2017}

Indeks Pembangunan Manusia Kabupaten Bojonegoro meningkat setiap tahun dengan rata-rata 1.09 persen pertahun. Gambar dibawah menunjukan pencapaian nilai IPM dari tahun 2010 hingga 2017. Pada tahun 2017 pencapaian IPM Kabupaten Bojonegoro sebesar 67.28 atau meningkat 0,55 point $(1,16 \%)$ dari tahun $2016(66,73)$. Angka pencapaian IPM Kabupaten Bojonegoro sebesar 67,28 masih dibawah pencapaian IPM Propinsi Jawa Timur yang sebesar 70,27. Peringkat IPM Kabupaten Bojonegoro di tahun 2016 menduduki peringkat kedua puluh delapan (26) se Propinsi Jawa Timur. Peringkat ini sama dengan tahun sebelumnya, tidka mengalami peningkatan meski nilai IPM naik. 


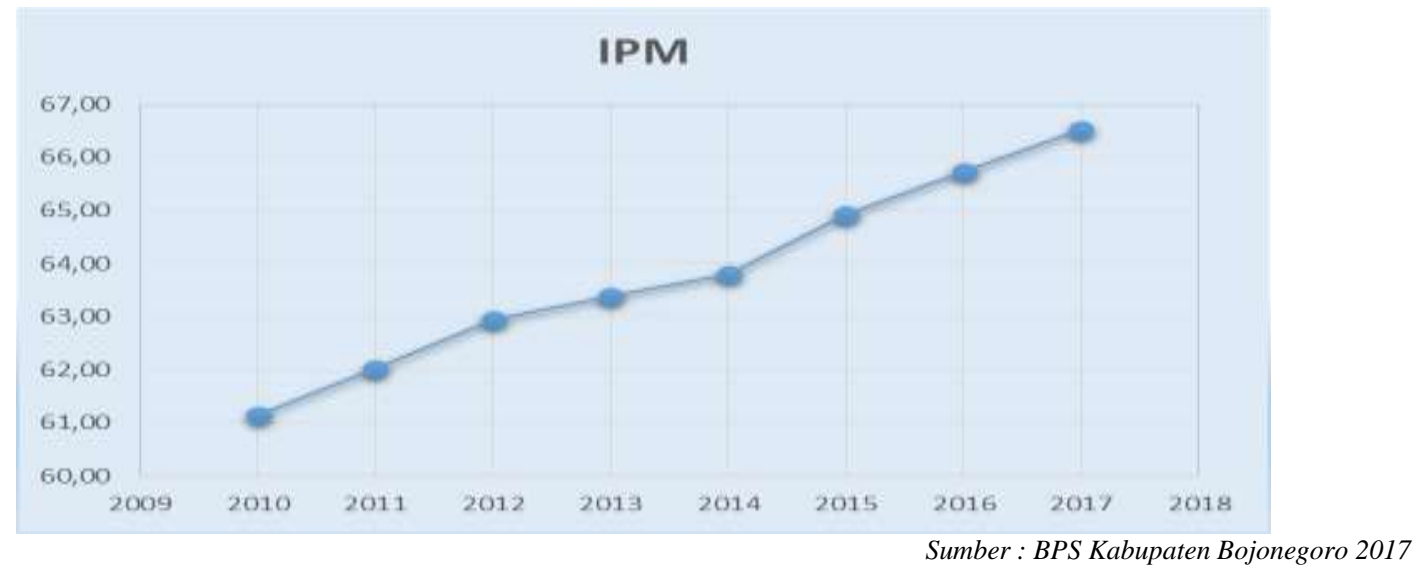

Capaian nilai Indeks Pembangunan Manusia (IPM) menentukan peringkat, namun tidak mutlak untuk menilai keberhasilan pembangunan manusia. Akselerasi peningkatan capaian IPM mengalami peningkatan yang signifikan sebesar $1,4 \%$ pada tahun 2015 dan pada tahun 2016 dan 2017 peningkatan nya mengalami penurunan yakni sebesar $0,8 \%$.

\section{Perkembangan Komponen IPM}

United Nations Development Programmes (UNDP) telah merekomendasikan penggunaan IPM untuk mengukur keberhasilan atau kinerja suatu negara dalam bidang pembangunan manusia. Sebagai sebuah indeks komposit yang dapat mencerminkan kinerja pembangunan manusia, indeks pembangunan manusia (IPM) dapat dibandingkan antarwilayah dan antarwaktu. Bahkan nilai IPM suatu daerah menjadi tidak bermakna jika tidak dibandingkan dengan waktu lainnya.

\section{Tabel 4}

Indeks Pembangunan Manusia (IPM) dan Komponen IPM

Kabupaten Bojonegoro Tahun 2012-2017

\begin{tabular}{|c|c|c|c|c|c|}
\hline $\begin{array}{c}\text { IPM dan } \\
\text { Komponennya }\end{array}$ & IPM & AHH & EYS & MLS & RPP \\
\hline 2012 & 64.20 & 69.98 & 11.74 & 5.8 & 8809.44 \\
\hline 2013 & 64.85 & 70.07 & 12.04 & 5.9 & 8934.19 \\
\hline 2014 & 65.27 & 70.11 & 12.08 & 6.14 & 8963.65 \\
\hline 2015 & 66.17 & 70.51 & 12.09 & 6.64 & 8993.21 \\
\hline 2016 & 66.73 & 70.67 & 12.11 & 6.65 & 9420 \\
\hline 2017 & 67.28 & 70.83 & 12.34 & 6.71 & 9553 \\
\hline
\end{tabular}

Sumber: BPS Kabupaten Bojonegoro 2017

Tingkat pencapaian pembangunan manusia di Kabupaten Bojonegoro yang digambarkan oleh IPM, pada tahun 2012 sebesar 64.2 dan terus meningkat hingga tahun 2017 sebesar 67.28. Selama tahun 2012 sampai dengan tahun 2016, pertumbuhan tertinggi IPM terjadi pada tahun 2015 sebesar 0.9. poin Jika dibandingkan dengan keadaan tahun 2015, IPM tahun 2014 telah terjadi peningkatan sebesar 1,25 persen. IPM Kabupaten Bojonegoro tahun 2016 sebesar 67,51 dan terus meningkat pada tahun 2017 menjadi 67,Peningkatan angka IPM menjadi 67,51 tersebut menandakan arah pembangunan daerah yang mulai berpihak kepada peningkatan kualitas hidup manusia di Kabupaten Bojonegoro. 


\section{Angka Harapan Hidup (AHH)}

Salah satu aspek penting pembangunan manusia adalah kualitas fisik penduduk yang dapat dilihat dari derajat kesehatan penduduk. Komponen IPM yang digunakan untuk melihat derajat kesehatan penduduk adalah Angka Harapan Hdup ( $\mathrm{AHH}-\mathrm{e}_{\mathrm{o}}$ ). Gambar 2

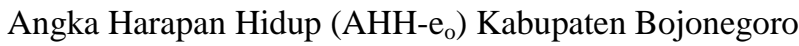
Tahun 2012-2017

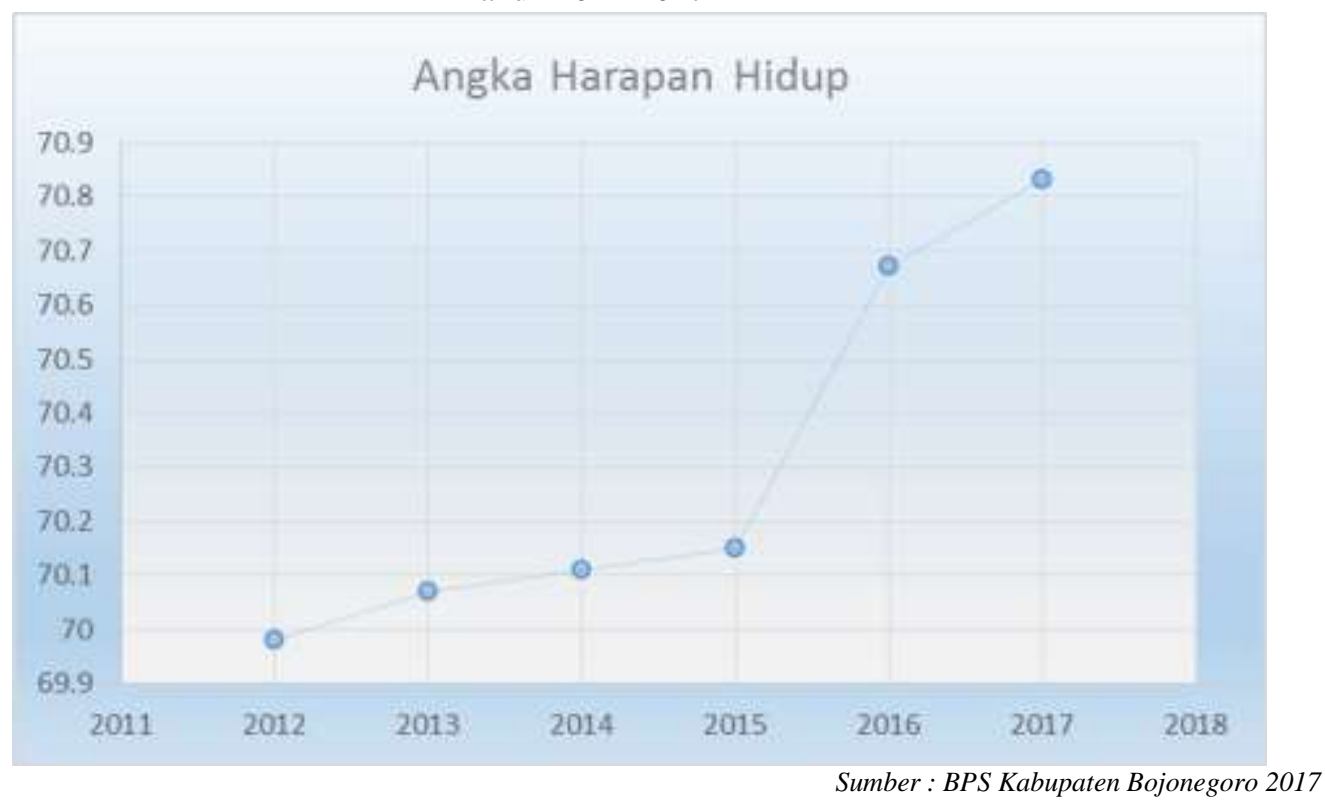

Angka Harapan Hidup Kabupaten Bojonegoro menunjukkan trend yang terus meningkat dan penduduk di Kabupaten Bojonegoro pada tahun 2017 memiliki peluang hidup hingga usia 70,83 tahun. Angka Harapan Hidup ini berlaku pada manusia yang masih berumur nol tahun atau baru lahir. Dengan kata lain, seorang bayi yang baru lahir di Kabupaten Bojonegoro pada tahun 2017 memiliki harapan untuk hidup hingga 70,83 tahun ke depan. Variabel Angka Harapan Hidup $\left(\mathrm{e}_{\mathrm{o}}\right)$ mencerminkan "lama hidup" sekaligus "hidup sehat" suatu masyarakat. Hasil perhitungan Angka Harapan Hidup akan lebih berbobot jika ada perbandingannya dengan periode waktu sebelumnya atau dengan daerah lain. Sebelu tahun 2017, angka harapan hidup 70,11 tahun di tahun 2016. Pada tahun 2014, AHH sebesar 70,75 tahun dan terus meningkat hingga tahun 2015 sebesar 70,16 tahun. Hal tersebut memberikan gambaran bahwa terjadi peningkatan kualitas kesehatan masyarakat di Kabupaten Bojonegoro yang ditandai dengan peningkatan angka harapan hidup.

\section{Rata-Rata Lama Sekolah dan Harapan lama Sekolah}

Pendidikan merupakan proses pemberdayaan peserta didik sebagai subyek sekaligus obyek dalam membangun kehidupan yang lebih baik. Pendidikan sangat berperan sebagai faktor kunci dalam peningkatan kualitas sumber daya manusia. Komponen kedua dalam penghitungan indeks pembangunan manusia berkaitan erat dengan data-data pendidikan. Komponen pendidikan dalam IPM dihitung dengan dua indikator, yaitu rata-rata lama sekolah dan harapan lama sekolah. 


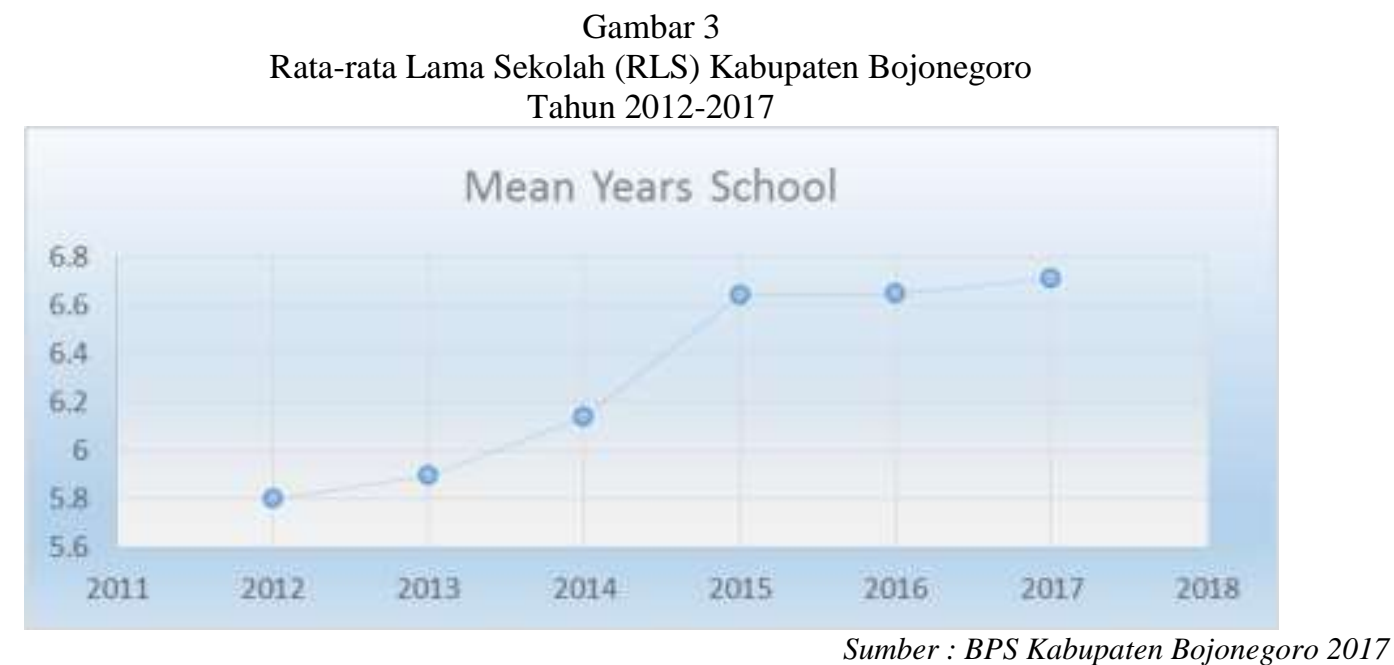

Rata-rata lama sekolah penduduk Kabupaten Bojonegoro menunjukkan trend yang terus meningkat dan rata-rata lama sekolah Kabupaten Bojonegoro pada tahun 2017 sebesar 6,71 tahun. Dengan kata lain, penduduk Kabupaten Bojonegoro pada tahun 2017 rata-rata menjalani pendidikan formal selama 6,71 tahun atau setara SMP Kelas I. Variabel Rata-rata lama sekolah (RLS) mencerminkan kualitas pendidikan suatu masyarakat. Hasil perhitungan rata-rata lama sekolah akan lebih terlihat jika ada perbandingannya dengan periode waktu sebelumnya. Sebelum tahun 2014, rata-rata lama sekolah di Kabupaten Bojonegoro masih di bawah 6 tahun dengan pertumbuhan tertinggi dicapai pada tahun 2015 mencapai hamper 4 persen dari 5,9 menjadi 6,14. Pada tahun 2012, RLS sebesar 5.51 tahun dan terus meningkat hingga tahun 2015 sebesar 6,14 tahun hingga akhirnya pad atahun 2017 mencapai angka 6,71 tahun. Hal tersebut memberikan gambaran bahwa terjadi peningkatan kualitas pendidikan masyarakat di Kabupaten Bojonegoro yang ditandai dengan peningkatan rata-rata lama sekolah. Akan tetapi pendidikan masih harus menjadi perhatian penting di saat ini. Dilihat dari rata- rata lama sekolah selama lima tahun terakhir masih dibawah tujuh tahun, yang menandakan masih membutuhkan usaha keras dari semua pihak untuk mencapai pendidikan 9 tahun.

Harapan Lama Sekolah Kabupaten Bojonegoro Tahun 2012-2017

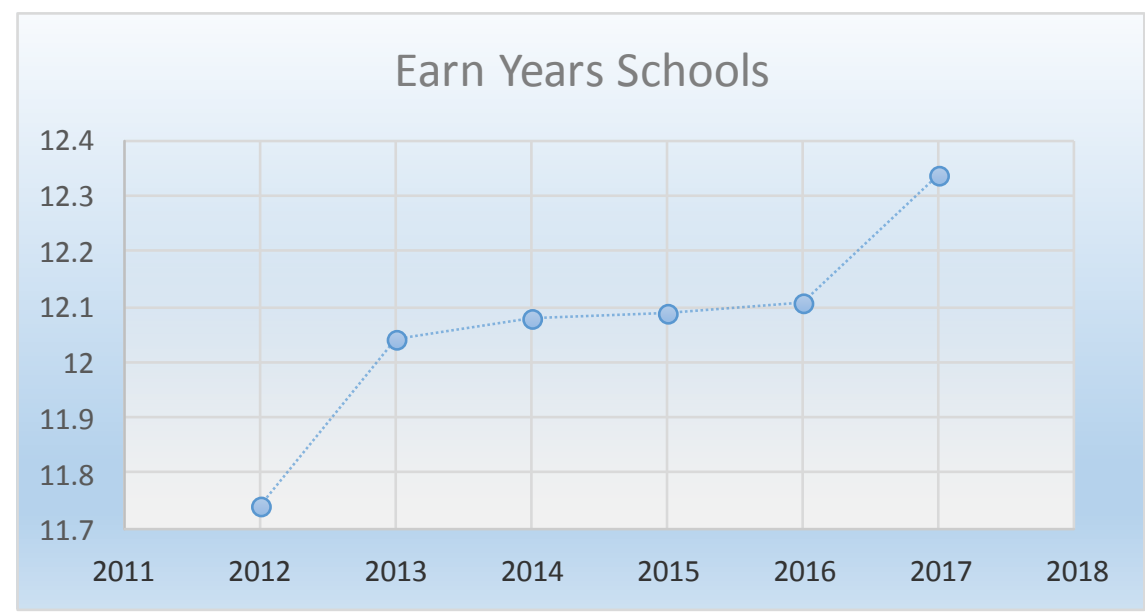

Sumber : BPS Kabupaten Bojonegoro 2017 
Harapan lama sekolah Kabupaten Bojonegoro menunjukkan trend yang terus meningkat dan harapan lama sekolah Kabupaten Bojonegoro pada tahun 2017 sebesar 12,34 tahun. Dengan kata lain, penduduk Kabupaten Bojonegoro yang masih bersekolah pada tahun 2017 memiliki harapan untuk menjalani pendidikan formal selama hampir 12 tahun atau setara dengan Sekolah menengah tingkat atas.

Selain variabel rata-rata lama sekolah, variabel harapan lama sekolah termasuk indikator pencapaian kualitas pendidikan suatu masyarakat. Hasil penghitungan harapan lama sekolah akan lebih berarti jika ada perbandingannya dengan periode waktu sebelumnya. Sebelum tahun 2013, harapan lama sekolah masih dibawah 12 tahun dengan pertumbuhan tertinggi mencapai hamper 3 persen di tahun 2016.Yakni 12,11 menjadi 12,34 di tahun 2017. Hal tersebut memberikan gambaran bahwa terjadi peningkatan kualitas pendidikan masyarakat di Kabupaten Bojonegoro yang ditandai dengan peningkatan harapan lama sekolah.

\section{Pengeluaran Perkapita Riil Disesuaikan}

Suatu masyarakat yang ideal selain harus memenuhi kondisi peluang hidup panjang dan sehat serta tingkat pendidikan dan ketrampilan yang memadai, juga harus mempunyai peluang bekerja dan berusaha yang memadai sehingga memperoleh sejumlah uang yang memiliki daya beli (purchasing power). Pemenuhan kebutuhan seperti itulah yang dicoba diukur dengan pengeluaran per kapita disesuaikan.

Tabel 5

Persentase Penduduk Menurut Golongan Pengeluaran Perkapita Sebulan di Kabupaten Bojonegoro, 2016 (Ribu Rupiah)

\begin{tabular}{|l|c|}
\hline \multicolumn{1}{|c|}{ Golongan Pengeluaran Per Kapita Sebulan (Rp) } & Persentase (\%) \\
\hline$<149999$ & - \\
\hline $150000-199999$ & 0.32 \\
\hline $200000-299999$ & 9.73 \\
\hline $300000-499999$ & 37.36 \\
\hline $500000-749999$ & 23.63 \\
\hline $750000-999999$ & 15.40 \\
\hline $1000000+$ & 13.88 \\
\hline \multicolumn{2}{|c|}{ Sumber : Diolah dari Survei Sosial Ekonomi Nasional (SUSENAS) 2016 } \\
\hline
\end{tabular}

Hasil perhitungan pengeluaran per kapita penduduk Kabupaten Bojonegoro tahun 2016, banyak penduduk yang rata-rata pengeluaran per kapita per bulan disesuaikan berkisar sebesar Rp. 300000 - Rp. 499999 yakni, berjumlah 27,66 persen. Sementara pengeluaran per kapita disesuaikan tertinggi sebesar lebih dari Rp. 1000000 mencapai 18,78 persen. Salah satu hal yang menggembirakan adalah pada tahun 2016, sudah tidak ada pengeluaran per kapita disesuaikan per bulan dari penduduk Kabupaten Bojonegoro dengan pengeluaran di bawah Rp. 149999 per bulan, bahkan pengeluaran per kapita disesuaikan per bulan sebesar Rp. 150000 - Rp. 199999 hanya berjumlah 0.32 persen. Hal ini menunjukkan kemampuan daya beli masyarakat Kabupaten Bojonegoro pada tahun 2016 mengalami peningkatan. Kemampuan daya beli masyarakat erat kaitannya dengan kemampuan penduduk untuk mendapatkan penghasilan, yang juga berhubungan dengan masalah ketenagakerjaan. Semakin beragamnya lapangan pekerjaan di suatu daerah, mencerminkan banyaknya pilihan penduduk dalam meningkatkan pendapatannya untuk memenuhi beragam kebutuhan 
hidup. Berikut beberapa Faktor/Indikator penunjang pada Pegeluaran per Kapita yang disesuaikan.

\section{Pertumbuhan Ekonomi}

Sebagai salah satu indicator pengukuran Indeks Pembangunan dari sector ekonomi adalah pengeluaran perkapita yang di sesuaikan. Gambar berikut menggambarkan pergerakan besarnya pengeuaran perkapitan di Kabupaten Bojonegoro.

\section{Gambar 5}

Pengeluaran perkapita yang disesuaikan di Kapubaten Bojonegoro

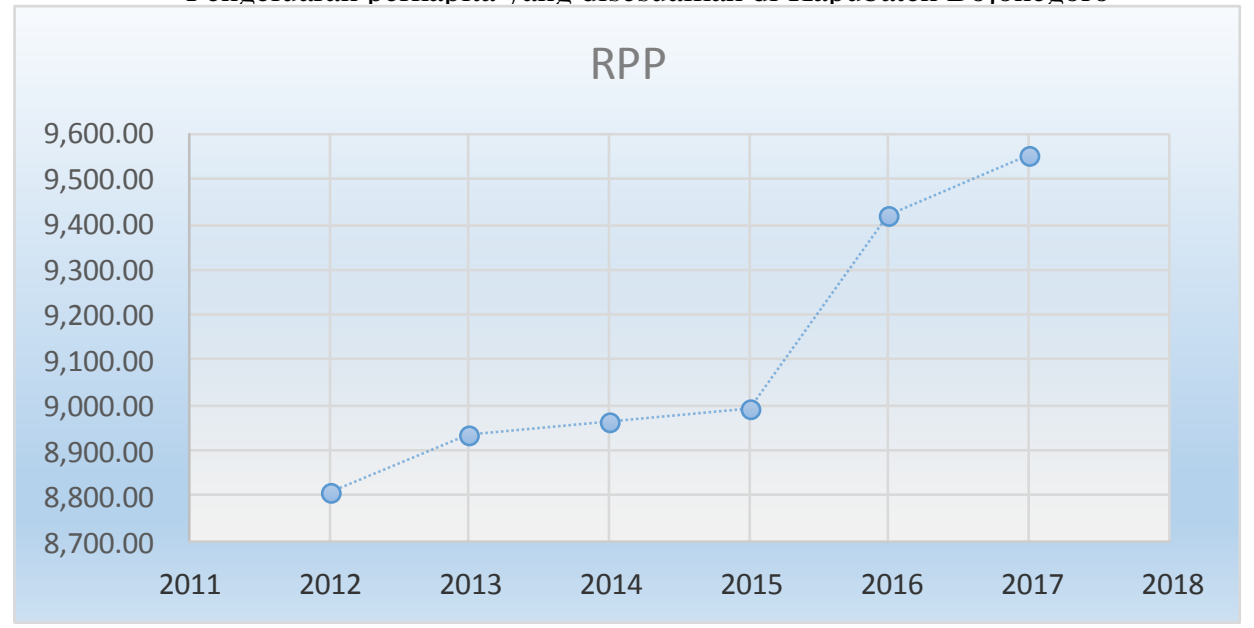

Trend yang terus naik dari grafik di atas juga merupakan bukti peningkatan pertumbuhan ekonomi di Kabupaten Bojonegoro. Tingkat pertumbuhan ekonomi Kabupaten Bojonegoro tahun 2016 sebesar 21,95 persen bahkan menduduki peringkat 1 se Jawa Timur.

Peningkatan Investasi memiliki konstribusi sebagai pengungkit terhadap bergeraknya pembangunan ekonomi di kabupaten Bojonegoro, Industri akan tumbuh jika Investasinya tumbuh dan pasarnya makin meluas.

Pertumbuhan ekonomi dipengaruhi oleh 2 (dua) macam faktor, yaitu faktor ekonomi dan faktor non ekonomi (jhingan, 2007:67).

a. Faktor ekonomi

1) Sumber Daya Alam

Sumber daya alam merupakan faktor utama yang mempengaruhi perkembangan suatu perekonomian daerah. Potensi sumber daya alam yang baik akan memudahkan pemerintah dan masyarakat dalam upaya menciptakan terobosan/inovasi baru. Kondisi geografis Kabupaten Bojonegoro yang memiliki luas wilayah sebesar $1.389,87 \mathrm{~km}^{2}$.

Luas tanah sawah Kabupaten Bojonegoro sebesar 130,15 $\mathrm{km}^{2}$ atau sekitar 9,36\% dan luas tanah kering adalah $1.259,72 \mathrm{~km}^{2}$ atau sekitar $90,6 \%$. Sebagian besar dari tanah sawah adalah sawah tadah hujan sebesar 51,53\%, dan sebagian besar dari tanah kering adalah untuk tanaman kayu-kayuan sebesar 35,89\%. Dimana Kabupaten Bojonegoro terletak pada alam yang bervariasi dan sangat kaya akan sumber daya alam yang mempunyai tanah yang subur dan juga banyak terdapat perbukitan.

Topografi Kabupaten Bojonegoro sebagian besar berupa pegunungan dan perbukitan sehingga menjadikan penggunaan lahan yang ideal pada kawasan tersebut berupa kawasan hutan. Hal ini menyimpan potensi hutan yang cukup besar. Dari potensi hutan ini sebagian akan dihasilkan berbagai jenis kayu yang tidak hanya diminati oleh 
masyarakat sekitar tetapi juga dipasarkan keluar Kabupaten Bojonegoro. Hutan di Kabupaten Bojonegoro terbagi menjadi hutan produksi yang luasnya mencapai $87,89 \%$ dari luas hutan yang ada, sedangkan sisanya $12,10 \%$ adalah hutan lindung. Luas areal hutan rakyat meningkat dikarenakan adanya penanaman tanaman kayu-kayuan yang cukup besar terutama karena adanya Penelitian pengembangan baik dari dukungan APBD Kabupaten, APBD Provinsi dan APBN maupun bantuan dari mitra usaha, pembuatan bedengan tanaman secara swadaya dan pembuatan kebun bibit rakyat. Hal ini mengindikasikan bahwa kesadaran masyarakat untuk turut serta dalam pelestarian hutan semakin meningkat. Berikut adalah kondisi topografi Kabupaten Bojonegoro dapat dirinci sebagai berikut:

a) Datar (kelas kelerengan 0-5\%) dengan luas 55,59 $\mathrm{km}^{2}$ atau $4 \%$ dari luas wilayah Kabupaten Bojonegoro;

b) Berombak (kelas kelerengan 6-10\%) dengan luas $138,99 \mathrm{~km}^{2}$ atau $10 \%$ dari luas wilayah Kabupaten Bojonegoro;

c) Bergelombang (kelas kelerengan 11-30\%) dengan luas $333,57 \mathrm{~km}^{2}$ atau $24 \%$ dari luas wilayah Kabupaten Bojonegoro;

d) Berbukit (kelas kelerengan 31-50\%) dengan luas $722,73 \mathrm{~km}^{2}$ atau $52 \%$ dari luas wilayah Kabupaten Bojonegoro;

e) Bergunung (kelas kelerengan > 52\%) dengan luas $138,99 \mathrm{~km}^{2}$ atau $10 \%$ dari luas wilayah Kabupaten Bojonegoro.

Kandungan mineral di Kabupaten Bojonegoro yang tercatat pada Dinas Pertambangan dan Energi bahwa Kabupaten Bojonegoro memiliki kandungan mineral berupa logam dan bukan logam yang tersebar pada beberapa kecamatan dan kelurahan atau desa.

2) Akumulasi Modal

Salah satu factor pertumbuhan ekonomi terletak pada ketersedian dana/modal dari lembaga-lembaga keuangan dan koperasi guna mendukung IKM yang membutuhkan dana untuk kemajuan usahanya. Akumulasi modal ini adalah sebagian pendapatan yang ditabung atau diinvestasikan kembali dengan tujuan untuk memperbesar produksi dan pendapatan.

3) Kemajuan Teknologi

Pesatnya perkembangan teknologi yang cukup pesat mempunyai dampak perubahan yang berguna bagi kemajuan peningkatan produktivitas dan efisiensi dengan jumlah sumber daya yang terbatas. Kemajuan teknologi ini tidak hanya pada bidang industry tetapi juga pada bidang pendidikan, kesehatan, transportasi, jasa kontruksi dan lain-lain.

b. Faktor Non Eknomi

1) Faktor sosial budaya

Untuk mempercepat pembangunan/pertumbuhan eknomi dibutuhkan wilayah dengan kondisi yang aman dan kondusif. Dengan jumlah peduduk Kabupaten Bojonegoro sebanyak 552.307 jiwa yang terdiri dari beberapa agama dan suku termasuk wilayah yang aman dan kondusif. Hal ini disebabkan masih dijunjung tingginya nilainilai luhur budaya Indonesia, yang masih melekat di Kabupaten Bojonegoro yaitu gotong royong dan kerjasama yang digunakan untuk melandasi kebijakan pemerintah daerah dalam pembangunan perekonomian.

2) Faktor Manusia

Laju pertumbuhan penduduk berhubungan dengan tersedianya tenaga kerja yang 
membutuhkan pekerjaan guna mencukupi kebutuhan hidup. Selain itu untuk melihat atau menggambarkan tingkat kesejahteraan masyarakat adalah laju pertumbuhan angkatan kerja yang terserap di lapangan pekerjaan. Jumlah angkatan kerja yang besar Kabupaten Bojonegoro.

Serapan tenaga kerja di Kabupaten Bojonegoro masih terbilang rendah. Merujuk data dinsosnakertrans setempat, dari 3.285 pencari kerja pada tahun 2016 hanya sekitar 1.181 orang yang sudah mendapatkan pekerjaan.

Jumlah itu belum termasuk sisa pencari kerja tahun lalu sebanyak 6.066 orang. Dari jumlah tersebut, hanya sekitar 3.897 orang yang telah bekerja. Sementara di sepanjang tahun 2017 serapan tenaga kerja masih di bawah 1.100 orang. Angka pengangguran itu turun dibanding tahun sebelumnya. Tahun lalu tingkat pengangguran terbuka (TPT) (2016) di Bojonegoro mencapai 5.243 orang atau sekitar 1,08 persen. Sedangkan tahun 2017 persentasenya sekitar 0,97 persen dari jumlah angkatan kerja

3) Faktor Politik

Terpilihnya kepala daerah secara demokarsi di Kabupaten Bojonegoro telah berdampak pada setabilnya perkembangan ekonomi. Hal ini tercermin pada :

a. Komitmen pemerintah kabupaten Bojonegoro dalam membangun infrastruktur.

Pertumbuhan ekonomi yang positif akan mendorong peningkatan kebutuhan akan berbagai infrastruktur. Faktor infrastruktur jalan yang dimiliki oleh Kabupaten Bojonegoro sudah baik sehingga sangat mendukung pertumbuhan ekonomi. Banyak hal yang diperoleh dari sistem prasarana jalan terkait dengan pendapatan, aksesbilitas, lapangan kerja, reduksi biaya operasional, penghematan waktu, dan meningkatkan industri.

Tabel 6

Jalan Penghubung dari Ibukota Kecamatan ke Kawasan Pemukiman Penduduk Minimal Dilalui Roda 4 (m) Tahun 2013 - 2018 Kabupaten Bojonegoro

\begin{tabular}{|c|l|c|c|c|c|c|}
\hline \multirow{2}{*}{ No Indikator } & \multicolumn{5}{c|}{ Tahun } \\
\cline { 3 - 7 } & & $\mathbf{2 0 1 3}$ & $\mathbf{2 0 1 4}$ & $\mathbf{2 0 1 5}$ & $\mathbf{2 0 1 6}$ & $\mathbf{2 0 1 7}$ *) \\
\hline 1 & Jembatan Kondisi baik & 697 & 704 & 727 & 757 & 785 \\
\hline 2 & Jembatan Kondisi Sedang & 142 & 141 & 134 & 144 & 116 \\
\hline 3 & Jembatan Kondisi rusak ringan & 22 & 21 & 11 & 11 & 11 \\
\hline 4 & Jembatan Kondisi rusak berat & 14 & 9 & 3 & 7 & 7 \\
\hline 5 & Jumlah Jembatan & 875 & 875 & 875 & 919 & 919 \\
\hline & Proporsi Jembatan Kondisi Baik (\%) & 79,65 & 94,95 & 95,43 & 95,66 & 95,88 \\
\hline & Proporsi Jembatan Kondisi Sedang (\%) & 16,22 & 16,11 & 15,31 & 15,66 & 12,62 \\
\hline & Proporsi jembatan Kondisi rusak ringan (\%) & 2,51 & 2,4 & 1,25 & 1,19 & 1,19 \\
\hline & Proporsi jembatan Kondisi Rusak berat (\%) & 1,6 & 1,02 & 0,34 & 0,76 & 0,76 \\
\hline
\end{tabular}

Kondisi Jembatan di Kabupaten pada tahun 2017 berjumlah 919 buah, yang terdiri dari jembatan besi/kayu dan jembatan beton/komposit. Pada Tahun 2017 Jembatan dengan kondisi baik berjumlah 785 buah atau meningkat sebesar 14,26\% dibanding tahun 2013 yang berjumlah 687 buah. Jembatan dengan kondisi sedang berjumlah 116 atau menurun 18,31\% pada tahun 2017 dibandingkan tahun 2013 yang berjumlah 142 jembatan dengan kondisi rusak ringan sejumlah 11 buah atau menurun 50\% pada tahun 2017 dibanding tahun 2013 sejumlah 22 buah dan jembatan dengan kondisi rusak berat juga mengalami penurunan 50\% dari 14 buah pada tahun 2013 menjadi 7 buah pada tahun 2017. Sedangkan perkembangan kondisi jalan di Kabupaten Bojonegoro dapat di lihat pada table di bawah ini: 
Analisis Indeks Pembangunan Manusia (IPM) Kabupaten Bojonegoro (Endang Siswati dan Diah Tri Hermawati)

Tabel 7

Kondisi Jalan di Kabupaten Bojonegoro 2015-2017

\begin{tabular}{|c|c|c|c|c|c|c|}
\hline \multirow{2}{*}{ No } & \multirow{2}{*}{ Indikator } & \multicolumn{5}{|c|}{ Tahun } \\
\hline & & 2013 & 2014 & 2015 & 2016 & 2017 \\
\hline 1 & Panjang jalan $(\mathrm{km})$ & 628.789 & 628.789 & 628.727 & 628.790 & 649.840 \\
\hline 2 & $\begin{array}{l}\text { Panjang jalan kabupaten dalam } \\
\text { kondisi baik }(\mathrm{km})\end{array}$ & 496.107 & 519.240 & 525.710 & 556.910 & 571.000 \\
\hline 3 & $\begin{array}{l}\text { Panjang jalan kabupaten dalam } \\
\text { kondisi sedang }(\mathrm{km})\end{array}$ & 92.877 & 73.725 & 68.352 & 53.020 & 58.970 \\
\hline 4 & $\begin{array}{l}\text { Panjang jalan kabupaten dala kondisi } \\
\text { rusak }(\mathrm{km})\end{array}$ & 23.883 & 21.494 & 34.727 & 19.860 & 19.860 \\
\hline 5 & $\begin{array}{l}\text { Panjang jalan kabupaten dalam } \\
\text { kondisi rusak berat }(\mathrm{km})\end{array}$ & 15.922 & 14.330 & 0 & 0 & 0 \\
\hline & Proporsi Kondisi Baik (\%) & 78,89 & 82,57 & 83,61 & 88,56 & 87,86 \\
\hline & Proporsi Kondisi Sedang (\%) & 14,77 & 14,19 & 10,87 & 8,43 & 9,07 \\
\hline & Proporsi Kondisi Rusak (\%) & 3,79 & 4,13 & 5,52 & 3,15 & 3,05 \\
\hline & Proporsi Konsisi Rusak Berat (\%) & 2,53 & 2,75 & 0 & 0 & 0 \\
\hline
\end{tabular}

b. Komitmen pemerintah kabupaten Bojonegoro dalam membangun Investasi.

Sektor Industri Pertanian menjadi sektor ekonomi yang mendongkrak kemajuan perekonomian di Kabupaten Bojonegoro. Perkembangan penanaman modal di Kabupaten Bojonegoro cenderung meningkat selama kurun tiga tahun terakhir. Peningkatan nilai investasi ini didapatkan dari empat sumber yaitu nilai investasi PMDN, Pemerintah Daerah, Pemerintah Provinsi dan Pemerintah Pusat.

Jumlah nilai investasi menggambarkan ketersediaan pelayanan penunjang yang dimiliki daerah berupa ketertarikan investor untuk meningkatkan investasinya di daerah. Tahun 2017 target yang ditetapkan adalah Rp 0,728 trilyun sedangkan realisasinya mencapai Rp. 1,138 trilyun. Dengan demikian nilai capaian 156,32 \%, dan dapat dikategorikan sangat baik. Faktor yang mendukung capaian investasi antara lain sumber daya alam yang mencukupi, meningkatnya sarana prasarana dan infrastruktur, birokrasi perizinan yang mudah, cepat dan transparan, serta adanya regulasi terhadap kepastian hukum yang jelas. Selain itu adanya investasi dari pemerintah pusat untuk pembangunan Waduk Tukul Karanggede Arjosari dan pembangunan Jembatan Jalur Lintas Selatan (JLS) di kabupaten Bojonegoro serta adanya dana dari pemerintah provinsi untuk pembangunan jalan lintas kabupaten dan pembangunan Pelabuhan Tamperan.

Untuk PMDN, pertumbuhan unit dan nilai investasi tercatat pada sektor penanaman modal dalam negeri (PMDN) fasilitas maupun non fasilitas. Pada tahun 2017 jumlah PMDN sebanyak 819 unit usaha dengan nilai investasi Rp. 602.271.412.143.

Data itu naik sekitar 7,8 persen dibanding dengan nilai investasi pada tahun 2016 sebesar Rp. 558.632.955.700 dengan 723 unit usaha. Pertumbuhan sektor usaha yang mendukung investasi adalah bidang usaha perikanan, kehutanan, industri kayu, hotel dan restoran serta industri mineral non logam. (pmptsp.Bojonegorokab.go.id)

\section{KESIMPULAN DAN REKOMENDASI Kesimpulan}

Pembangunan manusia sesungguhnya memiliki makna yang sangat luas. Ide dasar dari pembangunan manusia cukup sederhana, yaitu menciptakan pertumbuhan 
positif dalam bidang ekonomi, sosial, politik, budaya, dan lingkungan, serta perubahan dalam kesejahteraan manusia. Oleh karena itu, manusia harus diposisikan sebagai kekayaan bangsa yang sesungguhnya. Dengan berbekal konsep ini, tujuan utama dari pembangunan manusia harus mampu menciptakan lingkungan yang memungkinkan bagi rakyatnya untuk menikmati umur panjang, sehat, dan menjalankan kehidupan yang produktif.

Dari hasil pengamatan data Indeks Pembangunan Manusia (IPM) Kabupaten Bojonegoro selama periode tahun 2016-2017 maka dapat ditarik beberapa kesimpulan diantaranya:

1. Selama kurun waktu 2016 hingga 2017, pembangunan manusia di Kabupaten Bojonegoro menunjukkan perkembangan yang terus meningkat. Capaian IPM Kabupaten Bojonegoro pada tahun 2016 adalah 66,73 dan pada tahun 2017 sebesar 67,28 naik sebesar 0,23 point. Nilai IPM Kabupaten Bojonegoro bila menurut UNDP termasuk kedalam tingkat pembangunan "sedang". Dengan nilai tersebut IPM Kabupaten Bojonegoro berada pada peringkat ke-26 dari 38 kabupaten/kota se Jawa Timur, dan posisi ini tidak berubah dari tahun sebelumnya.

2. Pada tahun 2017 terjadi peningkatan pada seluruh indikator penyusun IPM. Indeks kesehatan yang diwakili dimensi Umur Panjang dan Hidup Sehat naik yang ditunjukkan dengan meningkatnya angka harapan hidup (AHH) menjadi 70,83 tahun dibandingkan tahun sebelumnya masih sebesar 70,67tahun. Selanjutnya Indeks pendidikan yang diwakli oleh dimensi naik dengan meningkatnya angka harapan lama sekolah (HLS) menjadi 12,34 tahun, dan rata-rata lama sekolah (RLS) menjadi 6,71 tahun dibandingkan tahun 2016. Indeks daya beli yang diwakili oleh dimensi pengeluaran juga naik yang ditunjukkan dengan meningkatnya pengeluaran per kapita per tahun menjadi 9,420 juta rupiah pada tahun 2016 dibandingkan tahun 2015 yang sebesar 9,553 juta rupiah per kapita penduduk per tahun.

3. Bila dilakukan perbandingan capaian IPM dengan daerah sekitar, maka IPM Kabupaten Bojonegoro $(67,28)$ masih kalah dengan IPM lamongan $(71,11)$; Kota Madiun (70,27); dan Nganjuk (70,69). Akan tetapi lebih tinggi dari Kabupaten Tuban $(66,77)$; dan Kabupaten Pasuruan $(66,69)$

\section{Rekomendasi}

Dari berbagai kesimpulan diatas yang telah diuraikan, maka berbagai saran yang dapat diberikan untuk meningkatkan Indeks Pembangunan Manusia di Kabupaten Bojonegoro, antara lain :

1. Konsep pembangunan manusia tidak berdiri sendiri sebagai sesuatu yang eksklusif. Konsep pembangunan yang ada harus berkaitan dengan konsep pembangunan manusia. Dan pembangunan manusia bukan hanya produk dari pertumbuhan ekonomi, tetapi sekaligus merupakan input penting untuk pertumbuhan ekonomi. Oleh karena itu, pertumbuhan ekonomi dan pembangunan manusia harus berjalan beriringan secara simultan.

2. Perlu kebijakan dan program pembangunan yang terencana dalam menentukan dan memilih prioritas atas kebutuhan masyarakat, sehingga pembangunan manusia dapat tepat sasaran. Berdasarkan indeks pada setiap komponen pembentuk IPM, terlihat bahwa pembangunan manusia kedepannya yang perlu diprioritaskan adalah pembangunan dalam bidang pendidikan, kesehatan dan indeks daya beli. Adapun dukungan kebijakan dapat di fokuskan sebagai berikut : 
a. Dimensi Pendidikan

1) Peningkatan partisipasi sekolah penduduk di tingkat pendidikan menengah pertama dan menengah atas, perlu pengembangan dan peningkatan sarana serta prasarana pendidikan,

2) Penambahan unit sekolah terutama untuk menengah atas

3) Perlu adanya program khusus untuk menjembatani kesenjanagn jumlah guru pns dan non pns

4) Mendorong guru untuk melaksanakan pembelajaran yang dapat mengembangkan kebersamaan dan kebiasaan berkolaborasi diantara peserta didik.

5) Memberikan perhatian lebih besar pada pendidikan non-formal dengan mengembangkan berbagai program strategis dan mensinergikan dengan pendidikan formal.

b. Dimensi Kesehatan

1) Pemerataan penyebaran fasilitas pelayanan kesehatan, sarana dan prasarana pada fasilitas kesehatan serta masih kurangnya tenaga kesehatan khususnya dokter spesialis sehingga perlu ditingkatkan untuk menunjang kualitas kesehatan penduduk.

2) Peningkatan Kerjasama Lintas Sektor untuk osialisasi masalah-masalah kesehatan pada sektor lain perlu dilakukan secara intensif dan berkala. Kerjasama lintas sektor harus mencakup pada tahap perencanaan, pelaksanaan dan penilaian serta melandaskan dengan seksama pada dasar-dasar pembangunan kesehatan.

3) Pengenbangan tenaga kesehatan harus menunjang seluruh upaya pembangunan kesehatan dan diarahkan untuk menciptakan tenaga kesehatan yang ahli dan terampil. Pengembangan tenaga kesehatan bertujuan untuk meningkatkan pemberdayaan atau daya guna tenaga dan penyediaan jumlah serta mutu tenaga kesehatan dari masyarakat dan pemerintah yang mampu melaksanakan pembangunan kesehatan. mesyarakat dan pemerintah perlu ditingkatkan dengan tenaga dan Penyeyediaan, jumlah serta mutu tenaga kesehatan dari masyarakat.

c. Dimensi Standar Hidup Layak

1) Pelaksanaannya program pembangunan tersebut mempunyai tujuan, sasaran, kebijakan dan program yang antara lain berguna untuk meningkatkan dukungan bagi penguatan usaha industri rumahtangga kecil dan menengah, keparawisataan, pengembangan perdagangan dan sistem distribusi, pengembangan ekspor, pengembangan koperasi dan UKM dan memberdayakan kemampuan usaha masyarakat miskin.

2) Dengan progam pembangunan ini kemampuan daya beli masyarakat berkaitan erat dengan kemampuan penduduk suatu daerah untuk mendapatkan penghasilan, yang juga berhubungan dengan masalah ketenagakerjaan. Semakin beragamnya lapangan pekerjaan di suatu daerah, mencerminkan banyaknya pilihan penduduk dalam meningkatkan pendapatannya untuk memenuhi beragam kebutuhan hidupnya.

3) Upaya pengembangan lapangan pekerjaan dapat dimulai dengan: Pemberian kemudahan dalam hal regulasi untuk Penelitian investasi, seperti pelayanan dan perijinan satu atap, regulasi untuk perlindungan tenaga kerja lokal dalam hal 
penentuan upah minimum kabupaten dan pengendalian stabilitas harga-harga kebutuhan pokok masyarakat sehingga daya beli masyarakat tetap stabil.

\section{DAFTAR PUSTAKA}

BPS. 2017. Indeks Pembangunan Manusia. Jakarta: Badan Pusat Statistik.

BPS Kabupaten Bojonegoro.2017. Indeks Pembangunan Manusia Kabupaten Bojonegoro. Bojonegoro: Badan Pusat Statistik Kabupaten Bojonegoro.

BPS Kabupaten Bojonegoro.2017. Produk Domestik Bruto Kabupaten Bojonegoro Menurut Pengaluaran Tahun 2012-2016. Bojonegoro: Badan Pusat Statistik Kabupaten Bojonegoro.

BPS Kabupaten Bojonegoro.2017. Statistik Kesejahteraan Rakyat Kabupaten Bojonegoro 2017. Bojonegoro: Badan Pusat Statistik Kabupaten Bojonegoro.

BPS Propinsi Jawa Timur (2017). Berita Resmi Statistik : Indeks Pembangunan Manusia (IPM) Jawa Timur. Surabaya: BPS Jawa Timur.

BPS Propinsi Jawa Timur (2016). Indeks Pembangunan Manusia Jawa Timur 1999, 2002, 2004- 2015. Surabaya: BPS Jawa Timur.

Dinas Kesehatan Kabupaten Bojonegoro. Profil Kesehatan 2015-2017

Dinas Pendidikan Kabupaten Bojonegoro. Profil Pendidikan 2015 -2017

Human Development Report (1990). Published for the United Nations Development Program (UNDP). New York, Oxford: Oxford University Press

Human Development Report (2016). Published for the United Nations Development Program (UNDP). New York, Oxford: Oxford University Press

Kuncoro, Mudrajad. 2003. Ekonomi Pembangunan: Teori, Masalah, dan Kebijakan Edisi Ketiga. UPP AMP YKPN. Yogyakarta.

Melliana,A dan Ismaini Zain. 2013. Analisis Statistika Faktor yang Mempengaruhi Indeks Pembangunan Manusia di Kabupaten/Kota Provinsi Jawa Timur dengan Menggunakan Regresi Panel.Jurnal Sains dan Sni Pomits Vol. 2, No.2.

Setiawan dan Dwi Endah Kusrini.2010.Ekonometrika.ANDI, Jogyakarta. 